\title{
Resources, Agriculture, and Economic Growth in Economies in Transition
}

\author{
by Thorvaldur Gylfason *
}

\begin{abstract}
This paper reviews some reasons why natural resource abundance and extensive agriculture appear to impede economic growth around the world. The paper presents empirical, cross-sectional evidence of various aspects of this relationship in the transition economies in Central and Eastern Europe and Central Asia since 1990. The essence of the argument is that heavy dependence on natural resources and agriculture may result in rent seeking (e.g., corruption) and policy failures (e.g., inflation) and may, moreover, discourage education, external trade, and genuine saving, thereby retarding economic growth. The paper concludes with a brief discussion of the policy implications of the analysis.
\end{abstract}

JEL O13, P24, Q32.

\footnotetext{
* Research Professor of Economics, University of Iceland; Research Associate, SNS-Center for Business and Policy Studies, Stockholm; and Research Fellow, CEPR and CESifo. This paper grew out of joint work with Randall K. Filer, Stepan Jurajda, and Janet Mitchell on "Markets and Growth in the Post-Communist World," which was supported by a grant from the Global Research Project of the World Bank. I thank my colleagues, and also Richard M. Auty, but neither they nor the World Bank should be held accountable in any way for the views expressed in this paper. Author's address: Faculty of Economics and Business Administration, University of Iceland, 101 Reykjavík, Iceland. Telephone: 354-525-4533/4500. Fax: 354-552-6806. Email: gylfason@hi.is
} 


\title{
Resources, Agriculture, and Economic Growth in Economies in Transition
}

\author{
Our country is rich, but our people are poor. \\ Vladimir Putin, President of Russia
}

\section{Introduction}

It is a widely held view, especially in natural-resource-abundant countries, that natural capital is an important pillar of economic performance and progress. True, an abundance of natural resources can be a source of steady income, at least as long as the resources are well managed or at any rate managed in a manner that can be sustained. Moreover, natural resource abundance is often accompanied by recurrent resource-related booms (the discovery of oil, for example), which lift the level of output, often quite considerably, and thus are perceived as a source of economic strength. Even so, the record seems to show that, in many countries, an abundance of natural resources has been associated with a slowdown in economic growth over time. If so, the economic benefits from natural-resource-related booms may not last forever.

To see this, consider a nation which discovers valuable oil reserves or mineral deposits within its jurisdiction. As incomes rise, the national economy will, at least for a while, clearly benefit from this discovery. However, if economic growth in the long run slows down as a result (for reasons to be discussed below), and nothing else changes, then eventually the nation will be worse off with its new-found natural resources than if it had not discovered them. Figure 1 shows two schedules depicting this hypothetical situation. The straight line ABCD shows steady economic growth from one year to the next. The schedule ABECF, on the other hand, shows what happens when new natural wealth is discovered and begins to be exploited at point B. Production surges upwards, but thereafter it grows less rapidly than before. At the intersection point of the two lines in the figure, point C, natural wealth begins to reduce the nation's standard of living. This is what is meant when natural resources are described as a 'mixed blessing' or even a 'curse' if they are not sufficiently well managed: they make nations rich for a while, true, but they tend to do so at the expense of economic growth over the long haul (see, e.g., 
Sachs and Warner, 1995a, Gylfason, 1999, and Gylfason, Herbertsson, and Zoega, 1999). Empirical evidence does not seem to indicate any significant difference in this respect between renewable resources (e.g., fisheries and forests) and nonrenewable resources (e.g., oil and minerals).

Figure 1 here.

So what are the main channels through which natural resource abundance may be harmful to economic growth? Before we answer this question, let us first, in Section II, ascertain its relevance for the Central and Eastern European and Central Asian transition economies. Let us then go on to discuss, in Section III, some of the possible channels through which natural resource abundance and agriculture may impede economic growth in the long run. In this section we also present some empirical evidence bearing on these possibilities, based on cross-sectional data from around the region in the 1990s and, for comparison, from around the world since 1960. The relationship between resource abundance, genuine saving, and growth is discussed in Section IV. We conclude the paper by discussing the policy implications of the analysis in Section V.

\section{Natural resource endowments and agriculture in transition economies}

It is not enough to look at current income flows to assess the wealth of nations and the living standards supported by that wealth. It is also necessary to examine the status and movement of key macroeconomic stock variables like natural-resource endowments, including the natural environment, and other national assets and liabilities in order to come to grips with the main determinants of economic growth over time. This is because high current flows of income that are attained by running down stocks (e.g., by depleting natural resources) cannot be sustained indefinitely. However, many of these national assets and liabilities—natural-resource endowments among them-are notoriously hard to measure.

Preliminary national wealth estimates for 1990 have been published by the World Bank (1995). They were made without purchasing-parity adjustment and included estimates for most transition economies (Table 1). National wealth is defined as the sum of (i) human capital, built up mainly through education and training, (ii) physical capital, 
accumulated through investment in machinery and equipment less depreciation, (iii) natural capital, comprising agricultural land, forests, minerals, and fossil fuels (but not fish resources), and (iv) social capital, reflecting infrastructure and institutions which, apart from individual factors such as corruption, cannot yet be measured and must, therefore, alas, be left out of the empirical analysis.

Table 1 indicates that, on average, the transition economies possess only a fraction of the national per capita wealth of the high-income countries-less than a tenth-and only twice the national per capita wealth of low-income countries. The table also indicates that the composition of the transition economies' national per capita wealth—that is, about 60 per cent human, 20 per cent physical, and 20 per cent natural—is, on the average, roughly similar to that of the high-income countries. Even so, some of the transition economies have a high share of natural capital in national wealth, especially Russia (70\%) and Turkmenistan (63\%). They are the only two countries in this group of twenty-two whose natural capital share is above the average for raw-material exporting countries. Yet, Russia's total national per capita wealth is less than one-fourth of the average per capita wealth of the high-income countries.

Table 1 here.

The World Bank's upgraded, but still admittedly tentative, estimates of the level and composition of total purchasing-power-parity-adjusted national wealth per person in 1994 do not include estimates for individual transition economies because of uncertainty about the quality of the data. For Central and Eastern Europe and Central Asia as a whole, it is estimated that one-half of natural capital consists of agricultural land, another 12 per cent comprises forests and protected areas, and the remaining 38 per cent represents minerals and fossil fuels. For this reason and others, the importance of agriculture to the national economy may be taken as a rough proxy for natural resource abundance, or at least for one aspect thereof. The last column of Table 1 shows that the transition economies, with the sole exception of Slovenia, are on average considerably more dependent on agriculture than the high-income countries. The average share of agriculture in the labor force of the transition economies in 1990 was 23 per cent, or almost four times that of the high-income countries. For comparison, the average share of value added in agriculture in Gross Domestic Product (GDP) in the transition economies, at 17 per cent in 1997, is 
more than eight times as high as that of the high-income countries. Hence, judging by their agriculture, the transition economies can be described as abundant in natural resources compared with the high-income countries, and also with the middle-income countries whose value added in agriculture amounted to 11 per cent of GDP in 1997, down from 21 per cent in 1970. From this perspective, concerns about the potentially adverse consequences of natural resource abundance for economic growth would seem to be relevant for the transition economies as a group, and certainly for some individual countries, especially Russia, which is by far the largest country in the group, and also Turkmenistan.

\section{Figure 2 here.}

Empirical evidence indicates a tendency for heavily agricultural economies to grow less rapidly than more industrialized and more service-oriented economies, other things being equal (Gylfason, 1999). Figure 2 illustrates this tendency. It shows a scatterplot of average per capita economic growth in 1960-1997 and the average share of agriculture in GDP over the same period in 162 countries. ${ }^{1}$ Each country is represented by a single dot in the figure. The negative relationship is statistically and economically significant. The correlation is -0.19 with a t-statistic of 2.5 . $^{2}$ The slope of the regression line indicates that each ten-point increase in the share of agriculture in GDP is associated with a decrease in per capita growth of almost 0.4 percentage points, a strong relationship in view of the fact that the average annual rate of per capita growth in the sample is only 1.1 per cent. ${ }^{3}$

The inverse relationship between economic growth and agriculture around the world is further illustrated in Table 2 which shows that in the 43 countries where agriculture accounted for less than 10 per cent of GDP in 1960-1997, the average annual rate of per capita growth was 2.1 per cent, compared with 1.2 per cent growth in the 41 countries

\footnotetext{
${ }^{1}$ From the original sample of all 165 countries for which the World Bank has published the requisite data, three countries had to be removed because of problems with their recorded (incredibly high!) growth rates: Equatorial Guinea, Dominica, and St. Vincent and the Grenadines.

${ }^{2}$ The correlation equals by definition the square root of $\mathrm{R}^{2}$, which is reported in the southeastern corner of the figure.

${ }^{3}$ The cluster of eight countries with annual growth rates below -4 per cent consists of Angola, Russia, and six other members of the former Soviet Union. Removing them from the sample strengthens the correlation from -0.19 to -0.25 , but does not materially affect the slope of the regression line.
} 
where agriculture accounted for between 10 and 20 per cent of GDP, and 0.5 per cent in the 78 countries where the share of agriculture in GDP was 20 per cent or more. The difference between the first and last growth figures shown in the table is statistically significant at the 0.05 level $(t=3.1)$, whereas the difference between the first and second growth figures is significant only at the less stringent 0.10 level $(t=1.6)$ and the difference between the second and third growth figures is insignificant $(\mathrm{t}=1.2)$. The upshot of this comparison is that, on the average, countries with a large agricultural sector (20\% of GDP or more) grow significantly more slowly than countries with a small agricultural sector (less than $10 \%$ of GDP).

These numbers are not surprising. Industrialization and service orientation have played key roles in the revolution of living standards that has taken place around the world in the twentieth century. The high-income countries became rich essentially by getting out of agriculture and, through industry, into services, whose (weighted) share in world output had reached 61 per cent in 1997. The unweighted average share of agriculture in GDP in our sample decreased from 32 per cent in 1960 to 23 per cent in 1997. This process will and must continue. The transition countries are no different from other countries in this regard. One of their most important economic, political, and social challenges in the twenty-first century will be to find ways to rapidly reduce their dependence on agriculture without major disruptions in order to make room for the continued expansion of the manufacturing, trade, and service industries that will have to become, as elsewhere, the mainstay of most of their people. This ongoing process will require economic policies and institutional structures that help foster static and dynamic efficiency gains, which will, if all goes well, result in increased economic growth over the long haul.

\section{Natural resources and economic growth: Evidence and explanations}

Why is it then that natural resource abundance may impede economic growth?

Let us first take a look at the empirical evidence. Figure 3 shows a scatterplot of per capita economic growth from 1960 to 1997 and the share of natural capital in national wealth in 1994 in 92 countries, all those for which the World Bank has prepared estimates of natural capital. The pattern that you see is statistically and economically 
significant. The correlation is -0.51 . An increase of 13 percentage points in the natural capital share from one country to another is associated with a decrease in per capita growth by one percentage point per year on average, other things being equal. Again, this is a fairly strong relationship in light of the fact that the average rate of per capita growth in the sample is 1.1 per cent per year over the period under review. The same pattern holds for rich countries and poor countries separately (Gylfason, 2000) as well as for various alternative measures of natural resource abundance, such as the share of primary exports in total exports or in GDP (as in Sachs and Warner, 1995a), the share of the primary sector in the labor force (as in Gylfason, Herbertsson, and Zoega, 1999), or simply the share of value added in agriculture in GDP, as in Figure 2 above. But recall that no transition countries are included in Figure 3 because they are not in the World Bank's sample.

Figure 3 here.

It goes without saying that the simple correlations shown in Figures 2 and 3 do not per se tell us much concerning cause and effect. Even so, they rhyme rather well with the results of multivariate regression analyses where other relevant determinants of economic growth were included among the explanatory variables and the attempt was made to distinguish cause from effect. The upshot is that the inverse relationship between natural resource abundance, however measured, and economic growth across countries seems rather robust in a statistical sense. While the possibility of reverse causation cannot be excluded (i.e., that rapid growth directs resources away from natural-resource-based industries), it would seem more natural to view natural resource endowments as exogenous and thus to infer from the statistical evidence that growth reacts to natural resources rather than the other way round.

Several explanations for this inverse relationship between natural resource abundance and economic growth have been offered in the literature that has emerged over the past few years (for a detailed analysis and summary of this literature as well as numerous case studies, see Auty, forthcoming). Let us now review them under four separate headings: (a) rent seeking, (b) policy failures, (c) education, and (d) the Dutch disease. 


\section{A. Rent seeking}

Natural resource abundance tends to be associated with the emergence of politically powerful special interest groups in and around the natural-resource-based industries. The rent seekers will strive, often with great success, to apply their political and financial clout to sway the government's economic policies in their favor at public expense. Their rent seeking can take many forms: they may manage to acquire ownership of or privileged access to state-owned or common-property resources like oil, minerals, or fishing banks and, by extension, other unrelated property, including communications media; they may try to keep foreign competition at bay; and they may use their sometimes ill-gotten gains to further their objectives in the political arena by, for example, filling the coffers of the political parties in power on which they depend for continued privileges. ${ }^{4}$ In many cases, the key to successful rent seeking is the ability to circumvent or thwart markets. The presence of huge rents in the market for natural resources, in particular, in conjunction with market imperfections and lax legal structures, creates opportunities for rent-seeking behavior on a large scale, thus diverting resources away from more socially fruitful economic activity.

\section{Figure 4 here.}

Figure 4, which covers all 45 countries for which we have the requisite data, shows the natural capital share in 1994 on the horizontal axis and the corruption perceptions index from Transparency International in 1996 on the vertical axis. ${ }^{5}$ The index extends from zero in the most corrupt countries to ten in those countries where corruption, as measured here, is practically nonexistent (as, for example, in Norway and New Zealand). The figure displays a clear and statistically significant pattern: corruption increases from one country to the next in accordance with the increase in natural capital. Specifically, when the natural capital share rises by six percentage points, the corruption perceptions index falls (i.e., corruption increases) by one point. The correlation is -0.33 (with $t=2.3$ ). A decrease in the corruption perceptions index (i.e., increased corruption) by two points from one country to the next has been shown to go along with a reduction in annual per

\footnotetext{
${ }^{4}$ On the causes and consequences of rent seeking, see Krueger (1974), Bhagwati (1982), and Gelb, Hillman, and Ursprung (1996).
} 
capita growth of one-half a percentage point on average (Mauro, 1995). Figure 4 thus indicates that an increase of 12 percentage points in the natural capital share from one place to another tends to reduce per capita growth by one-half a percentage point per year on the average, merely by encouraging corruption, if nothing else changes. This is a substantial effect—if it is an effect, that is, as reported by Leite and Weidmann (1999), for example, as opposed to a mere correlation. Reverse causation cannot be ruled out.

\section{Figure 5 here.}

Figures 5 and 6 tell essentially the same story about the transition countries, even if their growth record, for obvious reasons, must be restricted to the 1990s. Figure 5, which covers 20 countries (all those shown in Table 1 except Turkmenistan and Yugoslavia), ${ }^{6}$ displays, like Figure 4, a clear and statistically significant relationship between corruption and natural resource abundance when the latter is measured by the share of agriculture in the labor force in 1990. The correlation is -0.64 (with $t=3.6$ ). Notice that our sample includes countries with some of the lowest corruption perceptions indices on record: Azerbaijan and Uzbekistan, at 1.7 (like Indonesia) and 1.8, respectively, are only a hair's breadth higher on the honesty list than Nigeria (1.6) and Cameroon (1.5), which were perceived as the most corrupt countries of the world in 1999 according to Transparency International. In the northwestern corner of the scatterplot you can see Slovenia, the least agricultural and least corrupt country in the sample. The slope of the regression line indicates that an increase in the labor share of agriculture by 14 percentage points goes along with a decrease in the corruption perceptions index (i.e., increased corruption) by one point.

But what difference does this make for economic growth?

Figure 6 here.

Figure 6 shows the relationship between corruption and economic growth across the same 20 countries in 1990-1997. Again, we see a significant pattern with a correlation of 0.66 (with $t=3.7$ ). The slope of the regression line indicates that each one-point increase

\footnotetext{
${ }^{5}$ For description of the corruption perceptions index and related issues, see, for example, Gray and Kaufman (1998), Kaufman (1997), and Bardhan (1997).

${ }^{6}$ Specifically, the corruption perceptions index is unavailable for Turkmenistan and the growth figure is unavailable for Yugoslavia.
} 
in the corruption perceptions index (i.e., less corruption) is associated with an increase in the annual rate of per capita growth of more than three percentage points. Hence, by viewing Figures 5 and 6 together, we can see that if the share of agriculture in the labor force decreases by 5 percentage points, so that the corruption perceptions index increases by one-third of a point by Figure 5, then per capita growth increases by one percentage point by Figure 6, all else being the same. This is one example of how natural resource abundance in imperfect markets can lead to less growth, through corruption.

\section{B. Policy failures}

Another channel through which natural resource dependence may retard the rate of economic growth has to do with unsound policies. The market failure mainly responsible for rent seeking is compounded by policy failures. Like excessive, unconditional foreign aid, an abundance of natural resources can offer a false sense of security, a feeling that anything is possible. On the other hand, countries with no substantial natural resources may feel they have no margin for error and thus need to exercise care in their economic organization and policies. When resource-rich countries start running into difficulty, they tend to scarcely believe what is happening and try to encourage growth, for instance, with domestic investment projects and foreign borrowing. These cause inflation to soar, public finances and foreign debt to grow out of control, and produce, in the end, disappointing economic growth when the authorities are forced to take action to bring inflation and indebtedness under control. This in turn is followed by a spell of stagnation, or even deterioration of the standard of living, and public dissatisfaction, which set in motion forces to propel growth upwards once more, with a new surge, and the cycle repeats itself. $^{7}$ Economic development seesaws. During the years when economic growth is negligible or nonexistent, or even negative, the national wealth is depleted. This applies not only to physical capital but also to human capital and natural wealth, since in lean years the authorities are tempted to neglect education and step up utilization of natural resources. In years when growth takes a turn for the better, both the authorities and the public tend to lose sight of long-term trends. Only belatedly do people finally realize that long-term growth has been less on the average than they thought because it drops sharply

\footnotetext{
${ }^{7}$ This process is described in Sachs (1989) and Auty (1994).
} 
now and again. As a result, necessary reforms are often delayed. This problem of poor timing of policy reforms - too little, too late-results, however, not only from recurrent resource booms that blind the authorities to the need for reforms, but also from rent seeking as politically powerful interest groups in and around the natural-resource sector resist reforms (Auty, forthcoming).

So economic development is characterized by fits and starts, caused not only by inconsistency in economic policy but also by fluctuation in raw material prices in world markets. Prices for principal raw material commodities are far more prone to swings than are prices for other goods and services in general. This means that resource-rich countries are subject to more variable export earnings and more economic instability than are other countries. Upturns are followed by rapid growth, and sometimes by inflation as well. During downturns measures are often introduced to alleviate the problems of the export industries, sometimes including currency devaluation and foreign borrowing, with the result that inflation rages in lean years as well as in years of plenty.

Fits and starts disrupt economic activity in a way not dissimilar to inflation, that is, by increasing uncertainty and reducing trade and investment and, consequently, economic growth. The course of economic activity in one-basket economies is not only more irregular than in diversified systems, the former are also more sensitive to fluctuations caused by insufficient spreading of risk. When the dominant resource exploitation breaks down or fails for some reason, such as over-exploitation, catch failure, or collapse in world market price, the blow is often a staggering one because the capacity of the economy to sustain the shock is roughly inversely proportional to the dominance of the primary sector when everything was rosy.

Let us explore this hypothesis in the context of the transition countries under review here by using the inflation distortion or the implicit rate of inflation tax (i.e., the annual rate of inflation divided by one plus the inflation rate, an index which extends from zero to one) as our measure of policy failure and then correlating it with our preferred proxy for natural resource dependence, namely, the share of agriculture in the labor force in 1990, as before. Figure 7 shows that inflation is positively correlated with this measure of natural resource endowment across 21 of the 22 transition countries in our sample, all except Yugoslavia. The correlation is 0.36 , which, with so few observations, is not highly 
significant $(t=1.7)$. The slope of the regression line, for what it is worth, indicates that a 12 percentage point increase in the share of agriculture in the labor force goes along with an increase in the inflation distortion by 0.1 , which corresponds to an increase in the annual rate of inflation from, say, 50 per cent to 75 per cent. A similar pattern emerges when natural resource abundance is measured by the share of value added in agriculture in GDP. However, no clear association between natural resource abundance and inflation can be detected in the world economy as a whole, which may suggest that the correlation observed in Figure 7 is spurious.

Figure 7 here.

Figure 8 relates average per capita economic growth in 1990-1997 to the average inflation distortion over the same period. Here we see a strong and statistically significant correlation, -0.84 (with $t=6.8$ ). In this group of countries, therefore, economic growth is inversely correlated with inflation which, in turn, may perhaps to some extent, if Figure 7 is to be believed, be a consequence of the inefficiency associated with too much reliance on agriculture and too little scope accordingly for manufacturing, trade, and services. Even so, it seems likely that high inflation may be partly responsible for slow or negative growth either directly by distorting the use of real and financial capital in production (Gylfason, 1998a) or indirectly through other channels such as, for example, the overvaluation of the currency, to which we turn shortly.

Figure 8 here.

\section{Education}

A third channel through which natural resource abundance may slow down economic growth relates to human capital. Primary production generally makes lower educational demands of manpower than do other types of production - in manufacturing, trade, and services. This applies not least to agriculture in low- and middle-income countries, including most transition economies. As a result, workers released from primary production, such as farming, forestry, or mining, by and large have less general education, in the form of computer skills and knowledge of foreign languages, for instance, to offer new employers in manufacturing, trade, or services, because the 
proportion of unskilled laborers is generally higher in primary production than elsewhere. This is not the case across the board, however, because advanced technology in primary production requires various types of well-educated workers, as witnessed, for example, by high-tech oil-drilling operations and the mechanization and computerization of certain types of agriculture in industrial countries in recent decades. But insofar as the education of the primary production labor force is less overall than in other sectors of the economy, this would appear to explain in part why extensive primary production tends to impede growth, for education is an important source of economic growth, directly and indirectly. Empirical evidence suggests that school enrolment at all levels is inversely related to natural resource abundance while positively correlated with economic growth around the world (Gylfason, Herbertsson, and Zoega, 1999).

\section{Figure 9 here.}

We can see similar tendencies in our sample of transition countries in Figures 9 and 10, which cover the same 20 transition countries as Figures 5 and 6. Figure 9 shows a scatterplot of gross secondary-school enrolment in 1996 on the vertical axis and the share of agriculture in the labor force in 1990 on the horizontal axis. The pattern is significant, and suggests roughly a one-to-one trade-off between the two ratios. The correlation is 0.73 (with $\mathrm{t}=4.6$ ). This result, however, is sensitive to the inclusion of Albania, which is an outlier in the southeast corner of the scatter. If Albania is removed from the sample, the correlation decreases to -0.40 (with $\mathrm{t}=1.8$ ) and the slope of the regression is reduced from -0.9 to -0.4 . Even so, we have here a marginally significant pattern (not shown) which agrees with the overall pattern observed in the world as a whole. This inverse relationship between education and agriculture may reflect a market failure as well as a policy failure in a particular sense: that is, not only the failure of the authorities' commitment to education but also their failure to foster increased interest in education among the public and increased efficiency within the education system through marketbased incentives (including, for example, tuition fees as in China).

In Figure 10, we plot economic growth in 1990-1997 against secondary-school enrolment in 1996. Again, Albania is an outlier. When Albania is included in the sample (not shown), we observe a mildly positive correlation between economic growth and education, but the correlation is insignificant both statistically and economically. If, on 
the other hand, Albania is not included, then we have the pattern shown in Figure 10: the correlation is 0.57 (with $t=2.8$ ) and the slope of the regression is to 0.4 , indicating that a ten percentage point increase in the school enrolment ratio is associated with an increase in the rate of growth of output per head by four percentage points, other things being equal. Robust these results clearly are not, but they are suggestive of the kind of qualitative patterns that have emerged in larger samples covering the world as a whole and of the patterns that might be expected to emerge also in the transition economies as time passes and the economic turbulence of the 1990s has become a thing of the past.

Figure 10 here.

\section{The Dutch disease}

The fourth and last channel through which natural resource abundance may retard the rate of economic growth has to do with the Dutch disease, which can appear in many guises. In its most common form, the Dutch disease manifests itself through the ability of natural-resource based industries to live off rent extraction and thus to thrive with higher real exchange rates and to pay higher wage rates than other industries. These eclipsed industries smother as a result, unable to compete with inexpensive imports at home as well as in world markets. The consequence is typically a slump in manufacturing and other non-primary exports, and perhaps even in total exports relative to GDP if primary exports crowd out other exports guilder for guilder-or a result even worse (Gylfason, forthcoming). This may hurt growth because both the level of exports (and of imports: not only of goods, services, and capital, but also of ideas, innovation, and know-how) and their composition matter for growth. The level of exports, adjusted for country size, reflects the economy's openness, and openness generally is good for growth (Sachs and Warner, 1995b, Edwards, 1998, and Frankel and Romer, 1999). The composition of exports also matters. The real appreciation of the currency may hurt just the kind of hightech, capital-intensive or high-skill, labor-intensive manufacturing and service exports that are particularly conducive to rapid growth.

But is this a disease? Those who do not think so seem to view it as a matter of one sector benefiting partly at the expense of others, without seeing any macroeconomic damage being done. Those who view the Dutch disease as an ailment, by contrast, are 
concerned about the potentially harmful effects of the induced reallocation of resources between different sectors-from high-tech manufacturing, trade, and service industries to low-tech primary production, for example-on economic growth and diversification. According to this view, the empirical evidence of an inverse relationship between natural resource abundance and economic growth over long periods can be interpreted as a sign of the Dutch disease. If so, an effective cure may call for market-compatible government intervention - in the form of distortion-free resource rent fees, for example - to restore a healthy balance between different sectors in the economy.

Figure 11 shows the cross-sectional relationship between openness, measured by the difference between the actual average ratio of exports to GDP in $1990-1997^{8}$ and the average export ratio predicted by population alone (to adjust for country size) and the share of agriculture in the labor force in 1990. Specifically, the average export ratio in 1990-1997 was regressed on the logarithm of the average population (in thousands) in 1960-1997. The residual from the regression is our measure of openness (as in Gylfason, 1999). The fact that all but three of the countries in the sample lie above the horizontal axis shows that these are highly open economies relative to their size. The inclusion of Albania, once again an outlier, in the sample does not materially affect the regression line drawn through the scatterplot. The negative correlation between openness and agriculture is -0.72 (with $\mathrm{t}=4.4$ ).

Figure 11 here.

Figure 12 displays the cross-sectional pattern of economic growth and openness in the same sample, now excluding Albania, which remains an outlier. Without Albania, there is a weak positive correlation $(r=0.25)$ between economic growth and openness, but it is far from significant $(t=1.1)$. Further, if Albania is included in the sample, the positive correlation disappears altogether (not shown). Hence, it is not possible to state on the basis of these numbers that the growth performance of the transition economies in the 1990s has been directly associated with their openness to trade. A similar lack of (total) correlation between economic growth and openness can be observed in larger, world-

\footnotetext{
${ }^{8}$ In some countries the figures on export ratios actually extend back further into the past (in Hungary, they reach all the way back to 1970). In a few other cases, they start after 1990 (in
} 
wide cross-sectional samples, but significant positive partial correlation between economic growth and openness across countries and over time has been reported in some studies based on multiple regression analysis (Sachs and Warner, 1995b, Gylfason and Herbertsson, 1996, Edwards, 1998, and Frankel and Romer, 1999). The failure of the total correlation tests notwithstanding, there may be indirect links, however, between openness and growth-through inflation, for example. In other words, one of the reasons why inflation is inversely related to growth, as we saw in Figure 8, may well be that inflation hurts exports through the real exchange rate, all else being the same. Even so, the data do not bear out any significant correlation between inflation and openness. We let the matter rest there.

Figure 12 here.

\section{Genuine saving rates and economic growth}

Sustained economic growth requires high-quality saving and investment. High net saving rates do not necessarily stimulate growth if they are accompanied by rapid depreciation and depletion of physical and natural capital. For example, rapid depreciation of physical capital calls for investment to replace the depleted capital (i.e., replacement investment), thus rendering less of domestic saving available for fresh capital accumulation (i.e., net investment). Efficient financial markets are essential for saving to be channelled into high-quality investment. Bad banking reduces the quality of capital with time. An analogous argument applies to natural capital.

The World Bank's (1999) compilation of estimates of genuine saving rates can help sharpen the picture of the dependence of growth on saving and investment by taking the quality of physical and natural capital into consideration. Countries that run down their stocks of physical and natural capital will have low, perhaps even negative, genuine saving rates which, therefore, may be taken as a rough measure of the quality or sustainability of natural resource management, at least in a physical sense.

Genuine domestic saving differs from net domestic saving essentially by the rundown and depreciation of natural capital, adjusted by current expenditure on education, which

Azerbaijan, in 1993). The average export ratio for each country was computed from as many 
improves human capital. Put differently, genuine saving is, by definition, the difference between sustainable net national product and consumption, where sustainable net national product means the maximum amount that could be consumed without reducing the present value of national welfare along the optimum path (Hamilton, forthcoming). Genuine saving rates are higher than net saving rates in those countries where improvements in human capital outweigh the deterioration of natural capital, and conversely.

On average, genuine saving rates in the transition economies are lower than their net saving rates, indicating weak natural resource management with resource depletion to match (Table 3). This is in contrast to most industrial countries whose genuine saving rates are generally much higher than their net saving rates. In some of the transition economies, especially Azerbaijan, Kazakhstan, Russia, and Uzbekistan, genuine saving rates are far below their net saving rates. This appears to indicate that natural resources have been wasted, or at least have not been exploited in a sustainable fashion, as shown in the last column of Table 3.

Table 3 here.

Figures 13-16 are intended to throw further light on some of the linkages between economic growth and some of its underlying determinants that have been reviewed above. Figure 13 shows the cross-sectional relationship between genuine saving in 1997 (earlier figures are not available) and the labor share of agriculture in 1990 in our sample of transition economies. The correlation is -0.58 (with $t=2.9$ ). This may be taken as an indication that heavy dependence on agriculture and natural resources is conducive to poor resource management and consequent resource depletion. Figure 14 shows a positive relationship between honesty and genuine saving, which implies an inverse correlation $(r=-0.65, t=3.4)$ between corruption and genuine saving. Thus, it seems that corruption tends to corrode natural capital and perhaps discourage human capital accumulation as well. In fact, secondary education is inversely correlated with the corruption perceptions index in our sample, with $r=-0.65$ and $t=2.8$ (not shown). Figure 15 shows inflation and genuine saving rates across the transition economies.

observations as possible. 
Despite the three outliers at the bottom of the graph, we have here a significantly negative correlation $(\mathrm{r}=-0.52, \mathrm{t}=2.4)$.

Figures 13-15 here.

Figure 16 displays a scatterplot of economic growth and genuine saving. As one would expect, genuine (i.e., quality-adjusted) saving is positively correlated with per capita growth $(r=0.50, t=2.3)$. If we view genuine saving in 1997 , the only year for which we have such estimates, as an indication of what went on earlier in the decade, the scatterplot is consistent with the view that depreciation of natural capital, environmental degradation, and so on, by reducing genuine saving, can hurt economic growth. The slope of the regression line means that a one percentage-point increase in the genuine saving rate from one place to another goes along with an increase in the average annual per capita growth rate by 0.2 percentage points. The correlation between net (i.e., unadjusted) saving and growth is also positive (not shown), but weaker, economically as well as statistically. We can infer from this exercise that natural resource dependence, corruption, and inflation may impede economic growth not only through the channels that were discussed in earlier subsections, but also by discouraging genuine saving.

\section{Figure 16 here.}

The time has now come to wrap up the argument. Figure 17 presents a scatterplot of economic growth in 1990-1997 and the share of agriculture in the labor force in 1990. The correlation is -0.60 (with $t=3.2$ ). The slope of the regression indicates that an increase in the share of agriculture in the labor force by ten percentage points from one country to the next is associated with a decrease in the rate of growth of output per head by more than four percentage points, other things being equal. The transition economies thus conform to the pattern observed for the world economy as a whole from 1960 to date. Albania, an outlier as often before, has been excluded from the figure; if it is included, the correlation is considerably weaker $(r=-0.26)$ and less significant (with $\mathrm{t}=$ 1.7 ), and the slope of the regression decreases in absolute value from -0.41 to -0.14 .

Figure 17 here. 


\section{Policy reforms and growth}

We have presented above a rather intricate web of possible linkages between natural resource dependence, as measured by the weight of agriculture in the national economy, and various conceivable determinants of economic growth, determinants which, in their turn, may interact with one another. Figure 18 provides an overview of the linkages, with references to the figures describing each linkage. The upshot of the argument is that excessive dependence on agriculture, and natural resources more generally, may result in (a) rent seeking (and hence corruption) and (b) policy failures (and hence inflation) while discouraging (c) education, (d) external trade, and (e) genuine saving — thereby, through a mixture of some or all of these partially interactive channels, weakening economic growth performance. Several of these channels have been reasonably well documented in recent years in econometric studies of cross-sectional or panel data covering the world economy as a whole. Limited data and the unusual circumstances of the transition economies in the 1990s do not, however, permits us at this stage to undertake similar statistical analysis of their growth performance in this period. This explains the low-key, correlation-based, graphical approach taken here, which is merely meant to be suggestive of the kinds of linkages that may, judging by other countries' experience, be unveiled later by econometric research on economic growth in the formerly socialist economies.

\section{Figure 18 here.}

Suggestive as the results may seem, an inverse relationship between natural resource abundance and economic growth is by no means a foregone conclusion. Experience seems to indicate that it is not so much the existence of natural resources per se that hurts growth but rather the failure of public authorities to meet the policy challenge posed by natural resource abundance and to correct related market failures that does the damage. This challenge is both general and specific. To demonstrate this, a few examples will suffice.

Insofar as natural resource abundance tends to release forces that undermine sound economic management (the link from resource dependence to inflation), the general challenge means that the authorities need to put in place countervailing stabilizing mechanisms (e.g., banking legislation that secures the independence and accountability of 
the central bank and financial inspection authorities). In other words, economic stabilization is especially important in resource-rich economies. Here the existence of efficient and well developed financial markets that channel nonbank financing to public authorities and private enterprises can play a key role by reducing the pressure on the central bank to print money.

Similarly, insofar as natural resource dependence tends to distract attention and resources away from education, the authorities need to react by not only strengthening their own commitment to education but also by putting in place appropriate mechanisms that foster increased interest in education among the public (e.g., by creating increased scope for private-sector competition with publicly provided education at all levels). However, experience seems to show that public authorities in countries with predominantly public education systems have been reluctant to share their historical responsibility for the provision of education with the private sector; instead they have preferred to rely in part on what is essentially central planning in the field of education.

As yet another example, resource-rich countries need to take care to price their resources in accordance with prevailing prices in world markets. Underpricing of abundant domestic energy, for instance, will tend not only to encourage waste of valuable energy at home, but also to make domestic industries unduly energy-intensive, thus reducing their ability to compete against less energy-intensive firms in foreign markets. In resource-rich countries, therefore, market liberalization needs to be extended to the markets for natural resources.

The specific challenge concerns the mode of natural resource management, including agricultural policy. Natural resources need to be governed in a market-friendly, propertyrights-oriented manner. This means, for example, that the access to limited, commonproperty natural resources needs to be regulated as efficiently as possible-in essence, by price. Regulation by price through, for example, the selling or auctioning of oil drilling rights, pollution rights, or fishing permits in fair competition on a level playing field will generally foster orderly exploitation of non-renewable resources and sustainable exploitation of renewable resources. Regulation by price through such mechanisms would reduce rent dissipation and provide a distortion-free source of public revenue. Free and open trade in such rights and permits in open markets will also help achieve full 
efficiency, not only in the markets in question, but also from a macroeconomic and public-finance point of view. In Russia, for example, fishing rights are sold (not given away for free) by the government and then traded like private property, even with foreign nationals - an uncommon, but commendable practice, both on grounds of efficiency and fairness. Further, regulation by fair market price will generally help reduce the inequities that are often associated with other, less market-oriented means of regulation, those which tend to invite rent grabbing and other corrupt practices and thus undermine economic and social morale.

Agricultural policymakers ought to obey similar guiding principles. To promote efficiency, farm policies need to be liberalized around the world (with some exceptions, though, including Estonia and the Czech Republic, where full or at least extensive farm policy liberalization has already taken place). Liberalization of farm policies is especially important in heavily agricultural or resource-rich countries because they tend to have strong farm lobbies that resist reforms. The need to liberalize agriculture stems from the high costs imposed on consumers and taxpayers the world over by restrictive practices in the farm policy field, including, not least, the Common Agricultural Policy (CAP) of the European Union (EU). According to some estimates, the CAP may cost the member countries as much as the equivalent of about 3 per cent of their total GDP per year when the indirect costs that farm protection imposes on other sectors (manufacturing, trade, and services) are taken into account. Further, the interests of the aspiring EU members in Central and Eastern Europe also call for liberalization because their accession to the EU without CAP reform would be very expensive for the EU. Therefore, rather than keep the Central and Eastern European countries outside the gates of the EU or delaying their entry, the EU needs to radically revamp the CAP (and also the Common Fisheries Policy) in order to facilitate their accession within a reasonable time (see Gylfason 1998b).

But it is not enough that the EU liberalize the CAP; individual aspiring members must liberalize as well. This requires not only the implementation of market-friendly agricultural policies, but also massive privatization of farm land (in Russia, for example) and, more generally, various land reforms in the region. Most importantly, perhaps, there is a need for more and better education in rural areas in order to facilitate the reallocation of labor from agriculture to other occupations without unnecessary disruptions of the 
regional distribution of the population. Put differently, regional policies do not have to tie financial support to agriculture by distorting markets. Regional objectives can be attained more efficiently, without distorting markets, by supporting rural regions directly (by building roads, hospitals, and schools, for example)—and without any strings attached, so that the people themselves can decide whether to remain in agriculture or find something else to do. 
Table 1. National wealth: Human, physical, and natural, 1990

\begin{tabular}{|l|c|c|c|c|c|}
\hline & $\begin{array}{c}(1) \\
\text { Total per capita } \\
\text { national wealth } \\
\text { (US\$ thousands) }\end{array}$ & $\begin{array}{c}\text { Human } \\
\text { capital } \\
\text { (\% of total) }\end{array}$ & $\begin{array}{c}(3) \\
\text { Physical } \\
\text { capital } \\
\text { (\% of total) }\end{array}$ & $\begin{array}{c}\text { (4) } \\
\text { Natural } \\
\text { capital } \\
\text { (\% of total) }\end{array}$ & $\begin{array}{c}\text { Agriculture } \\
\text { \% of labor } \\
\text { force) }\end{array}$ \\
\hline Albania & 33 & 74 & 15 & 10 & 55 \\
\hline Azerbaijan & 14 & 67 & 25 & 6 & 31 \\
\hline Belarus & 53 & 79 & 11 & 10 & 20 \\
\hline Bulgaria & 23 & 61 & 15 & 24 & 13 \\
\hline Czech Rep. & 50 & 65 & 15 & 19 & 11 \\
\hline Estonia & 55 & 72 & 14 & 15 & 14 \\
\hline Georgia & 16 & 63 & 28 & 6 & 26 \\
\hline Hungary & 63 & 71 & 16 & 12 & 15 \\
\hline Kazakhstan & 31 & 79 & 19 & 1 & 22 \\
\hline Kyrgyz Rep. & 14 & 55 & 23 & 24 & 32 \\
\hline Latvia & 35 & 66 & 20 & 12 & 16 \\
\hline Lithuania & 24 & 64 & 30 & 9 & 18 \\
\hline Moldova & 22 & 77 & 19 & 4 & 33 \\
\hline Poland & 50 & 56 & 13 & 31 & 27 \\
\hline Romania & 17 & 70 & 17 & 13 & 24 \\
\hline Russian Fed. & 98 & 15 & 15 & 70 & 14 \\
\hline Slovak Rep. & 33 & 78 & 17 & 5 & 12 \\
\hline Slovenia & 111 & 67 & 16 & 16 & 6 \\
\hline Turkmenistan & 29 & 23 & 15 & 63 & 37 \\
\hline Ukraine & 30 & 77 & 17 & 6 & 20 \\
\hline Uzbekistan & 15 & 69 & 19 & 12 & 35 \\
\hline Yugoslavia & 71 & 18 & 54 & 28 & 30 \\
\hline Average & $\mathbf{4 0}$ & $\mathbf{6 2}$ & $\mathbf{2 0}$ & $\mathbf{1 8}$ & $\mathbf{2 3}$ \\
\hline $\begin{array}{l}\text { High-income } \\
\text { countries }\end{array}$ & 436 & 68 & 16 & 17 & 6 \\
\hline $\begin{array}{l}\text { Low-income } \\
\text { countries }\end{array}$ & 21 & 51 & 17 & 32 & 66 \\
\hline $\begin{array}{l}\text { Raw-material } \\
\text { exporters }\end{array}$ & 27 & 36 & 20 & 43 & $\ldots$ \\
\hline
\end{tabular}

Source: World Bank (1995, 1999). 
Table 2. Economic Growth and Agriculture, 1960-1997

\begin{tabular}{|c|c|c|}
\hline $\begin{array}{l}\text { Number of } \\
\text { countries }\end{array}$ & $\begin{array}{c}\text { Value added in } \\
\text { agriculture as per cent of } \\
\text { GDP on average 1960- } \\
1997\end{array}$ & $\begin{array}{c}\text { Annual average rate of growth of } \\
\text { per capita GNP 1960-1997 in per } \\
\text { cent (t-values within } \\
\text { parentheses) }\end{array}$ \\
\hline 43 & $0-10$ & $\begin{array}{c}2.1^{*} \\
(1.6)\end{array}$ \\
\hline 41 & $10-20$ & $\begin{array}{c}1.2 \\
(1.2)\end{array}$ \\
\hline 78 & $20-50$ & $\begin{array}{c}0.5^{* *} \\
(3.1)\end{array}$ \\
\hline
\end{tabular}

Source: Author's computations based on data from the World Bank (1999). 
Table 3. Genuine domestic saving rates, 1997

\begin{tabular}{|l|c|c|c|c|}
\hline & $\begin{array}{c}(1) \\
\text { Genuine } \\
\text { domestic saving } \\
(=(2)+(3)-(4)) \\
(\% \text { of GDP) }\end{array}$ & $\begin{array}{c}\text { Net domestic } \\
\text { saving } \\
(\% \text { GDP) }\end{array}$ & $\begin{array}{c}(3) \\
\text { Education } \\
\text { expenditure }(\% \\
\text { of GDP) }\end{array}$ & $\begin{array}{c}\text { Natural } \\
\text { resource } \\
\text { depletion (\% } \\
\text { of GDP) }\end{array}$ \\
\hline Albania & -23.5 & -25.6 & 2.8 & 0.6 \\
\hline Azerbaijan & -31.4 & -4.5 & $\ldots$ & 26.9 \\
\hline Belarus & 7.4 & 4.4 & 4.7 & 1.7 \\
\hline Bulgaria & 6.7 & 7.3 & 4.0 & 4.5 \\
\hline Czech Rep. & 14.8 & 11.2 & 5.3 & 1.7 \\
\hline Estonia & 8.2 & 7.9 & 4.3 & 4.0 \\
\hline Hungary & 23.0 & 18.9 & 5.2 & 1.2 \\
\hline Kazakhstan & -17.9 & 6.1 & $\ldots$ & 24.0 \\
\hline Kyrgyz Rep. & 5.0 & 3.6 & 4.3 & 2.9 \\
\hline Latvia & 3.1 & -2.1 & 6.5 & 1.2 \\
\hline Lithuania & 12.3 & 8.9 & 4.4 & 1.0 \\
\hline Poland & 12.5 & 9.3 & 5.7 & 2.3 \\
\hline Romania & 4.9 & 6.9 & 3.5 & 5.5 \\
\hline Russian Fed. & -1.6 & 5.3 & 4.1 & 11.1 \\
\hline Slovak Rep. & 16.6 & 12.9 & 5.0 & 1.3 \\
\hline Slovenia & 12.9 & 6.2 & 7.1 & 0.4 \\
\hline Ukraine & -3.4 & -2.1 & 4.6 & 6.0 \\
\hline Uzbekistan & 11.4 & 14.2 & 7.7 & 10.6 \\
\hline Average & 3.4 & 4.9 & 5.0 & 5.9 \\
\hline United States & 9.9 & 5.3 & 5.8 & 1.1 \\
\hline Indonesia & 20.5 & 25.6 & 0.9 & 6.2 \\
\hline
\end{tabular}

Source: World Bank (1999) and Hamilton (forthcoming). 


\section{References}

Auty, Richard M. (1994), "Industrial Policy Reform in Six Large Newly Industrializing Countries: The Resource Curse Thesis", World Development 22, 11-26.

Auty, Richard M. (forthcoming), "Reforming Resource-Abundant Transition Economies: Kazakstan and Uzbekistan," Ch. 17 in Auty (forthcoming).

Auty, Richard M. (ed.) (forthcoming), Resource Abundance and Economic Development: Improving the Performance of Resource-Rich Countries.

Bardhan, Pranab (1997), "Corruption and Development: A Review of the Issues", Journal of Economic Literature 35, September, 1320-1346.

Bhagwati, Jagdish (1982), "Directly-Unproductive, Profit-Seeking (DUP) Activities", Journal of Political Economy 90, October, 988-1002.

Edwards, Sebastian (1998), “Openness, Productivity and Growth: What do we Really Know?", Economic Journal 108, March, 383-398.

Frankel, Jeffrey A., and David Romer (1999), “Does Trade Cause Growth?”, American Economic Review, June, 379-399.

Gelb, Alan A., L. Hillman and H. W. Ursprung (1996), "Rents and the Transition", Background Paper, World Development Report 1996, World Bank, Washington, DC.

Gray, Cheryl W., and Daniel Kaufman (1998), "Corruption and Development", Finance and Development, March, 6-10.

Gylfason, Thorvaldur (1998a), “Output Gains from Economic Stabilization”, Journal of Development Economics 56, June, 81-96.

Gylfason, Thorvaldur (1998b), "Prospects for Liberalization of Trade in Agriculture," Journal of World Trade 32, February, 29-40.

Gylfason, Thorvaldur (1999), "Exports, Inflation, and Growth,” World Development 27, June, 1031-1057.

Gylfason, Thorvaldur (2000), "Nature, Power, and Growth”, Rapport 3, ECON—Center for Economic Analysis, Norway, January.

Gylfason, Thorvaldur (forthcoming), "A Nordic Perspective on the Dutch Disease”, Ch. 14 in Auty (forthcoming).

Gylfason, Thorvaldur, and Tryggvi Thor Herbertsson (1996), “Does Inflation Matter for Growth?," CEPR Discussion Paper No. 1503. 
Gylfason, Thorvaldur, Tryggvi Thor Herbertsson, and Gylfi Zoega (1999), “A Mixed Blessing: Natural Resources and Economic Growth," Macroeconomic Dynamics 3, June, 204-225.

Hamilton, Kirk (forthcoming), "The Sustainability of Extractive Economies", Ch. 3 in Auty (forthcoming).

Leite, Carlos, and Jens Weidmann (1999), "Does Mother Nature Corrupt? Natural Resources, Corruption, and Economic Growth?”, IMF Working Paper WP/99/85, July.

Kaufman, Daniel (1997), “Corruption: The Facts”, Foreign Policy 107, 114-131.

Krueger, Anne (1974), "The Political Economy of the Rent-Seeking Society“, American Economic Review 64, June, 291-303.

Mauro, Paolo (1995), "Corruption and Growth", Quarterly Journal of Economics 110, August, 681-712.

Sachs, Jeffrey D. (1989), "Social Conflict and Populist Policies in Latin America", NBER Working Paper No. 2897.

Sachs, Jeffrey D., and Andrew M. Warner (1995a), "Natural Resource Abundance and Economic Growth”, NBER Working Paper No. 5398.

Sachs, Jeffrey D., and Andrew M. Warner (1995b), "Economic Reform and the Process of Global Integration”, Brookings Papers on Economic Activity 1, 1-118.

World Bank (1995), “Monitoring Environmental Progress”, Environmentally Sustainable Development Series, World Bank, Washington, DC.

World Bank (1999), World Development Indicators, Washington, DC. 
Figure 1. Natural Wealth and Growth

National economic output

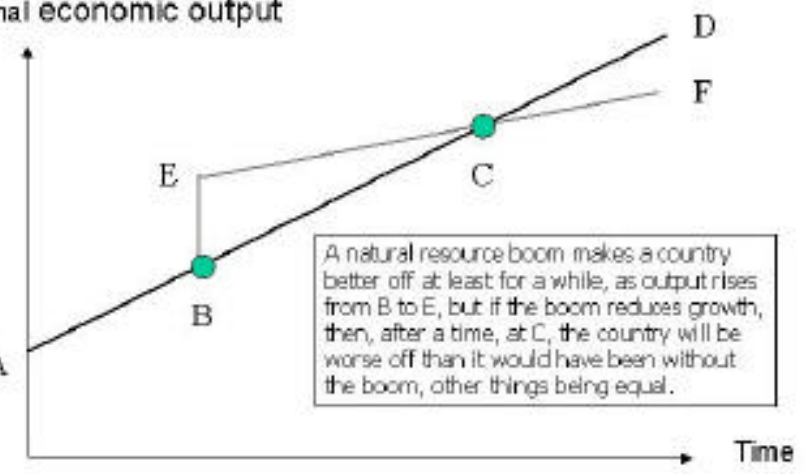

Figure 2. Economic Growth and Agriculture Around the World, 1960-1997

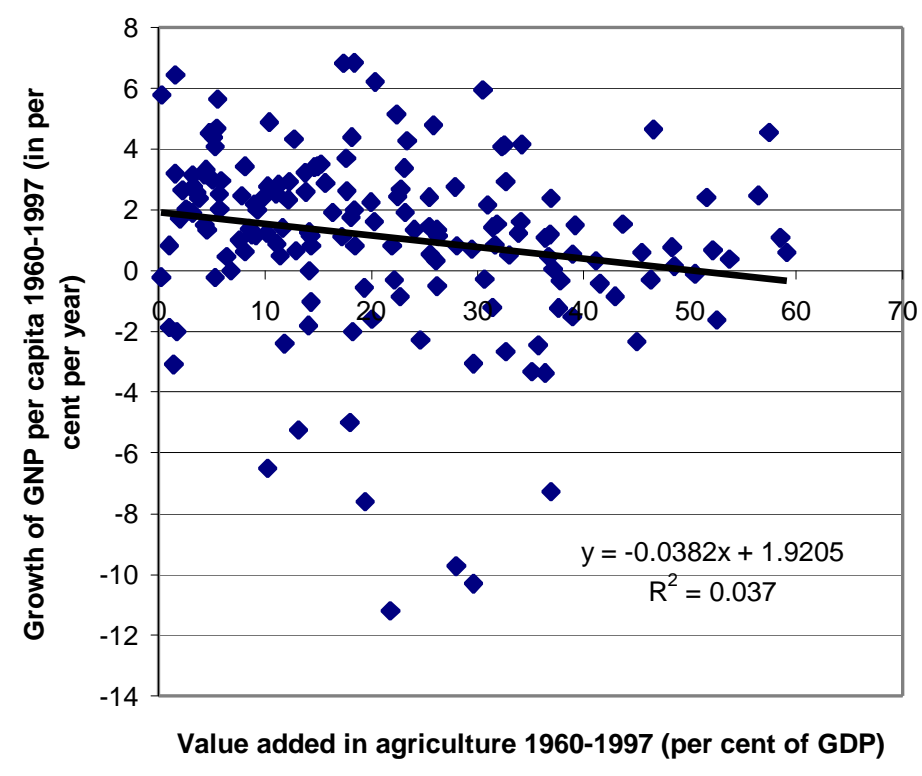


Figure 3. Economic Growth and Natural Capital Around the World, 1960-1997

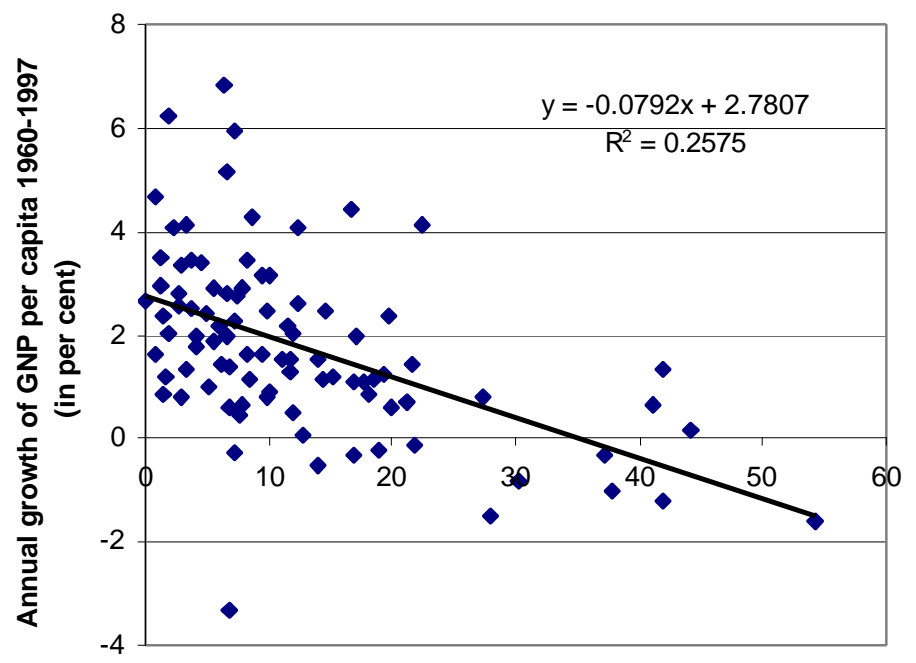

Share of natural capital in national wealth 1994 (in per cent)

Figure 4. Corruption and Natural Capital Around the World, 1994-1996

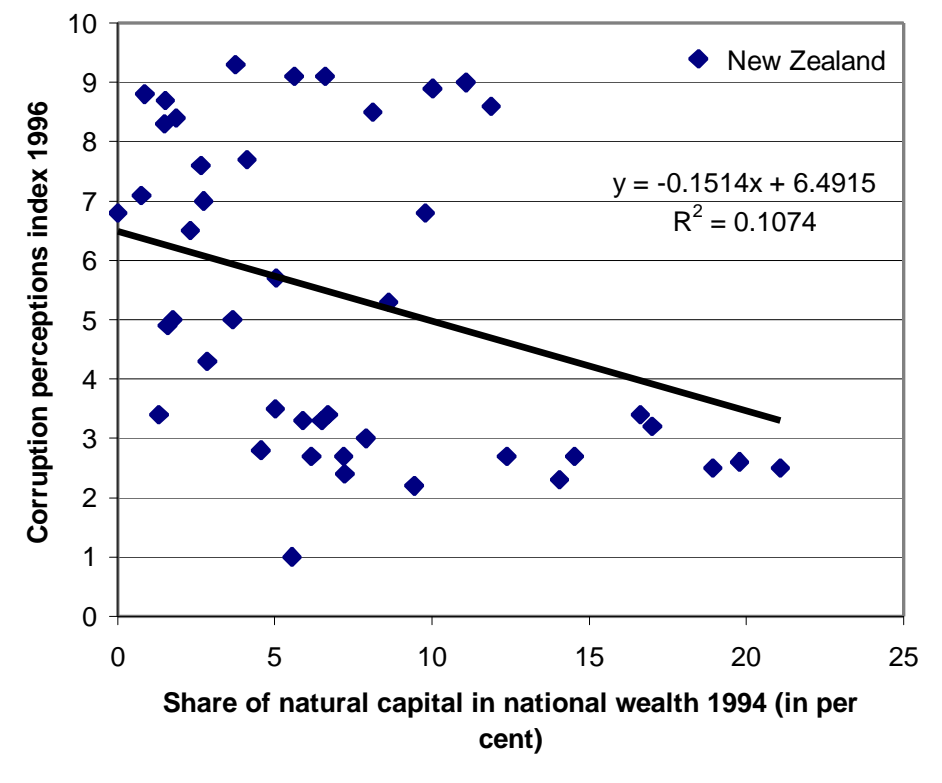



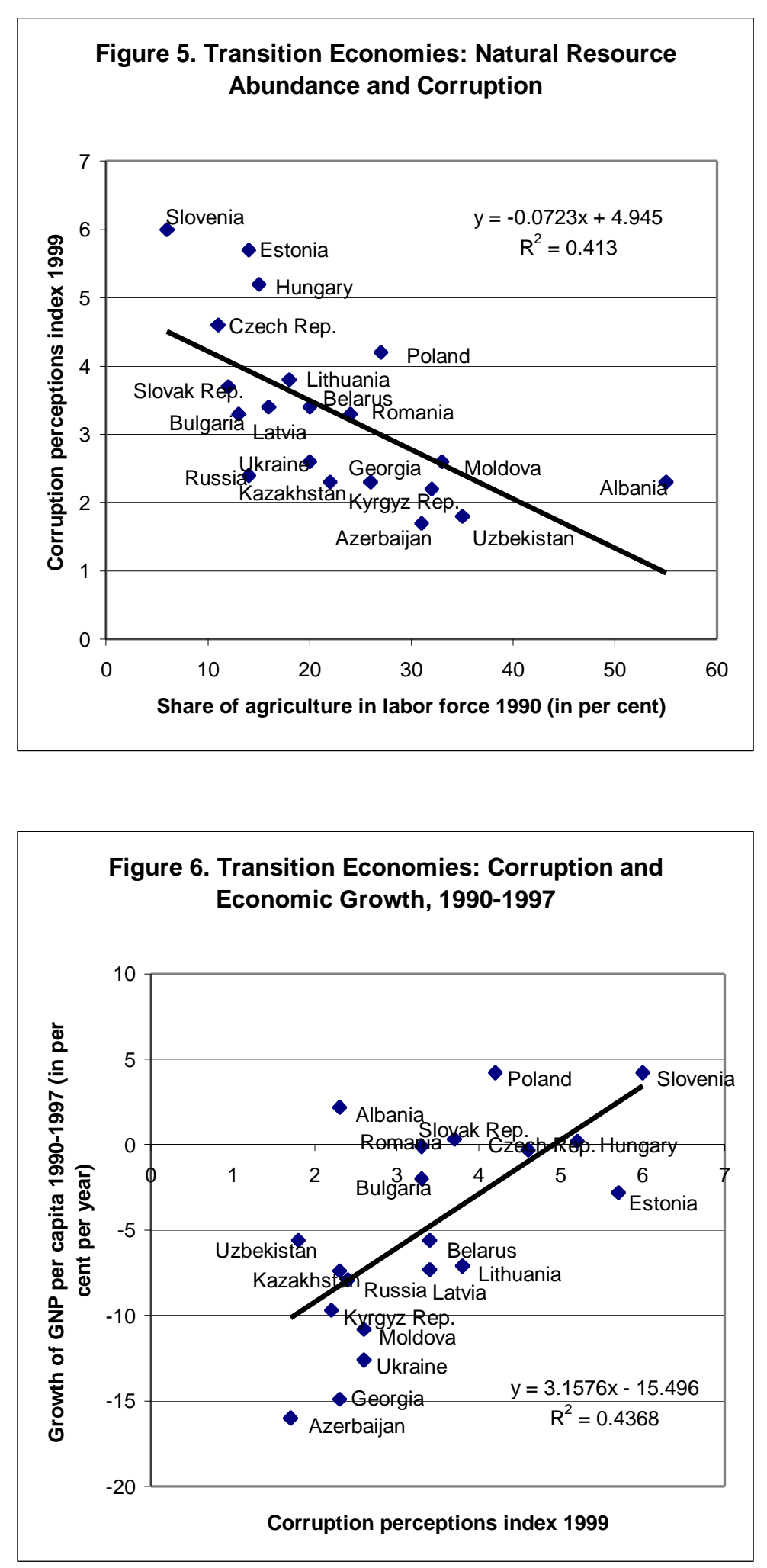
Figure 7. Transition Economies: Inflation and Agriculture, 1990-1997

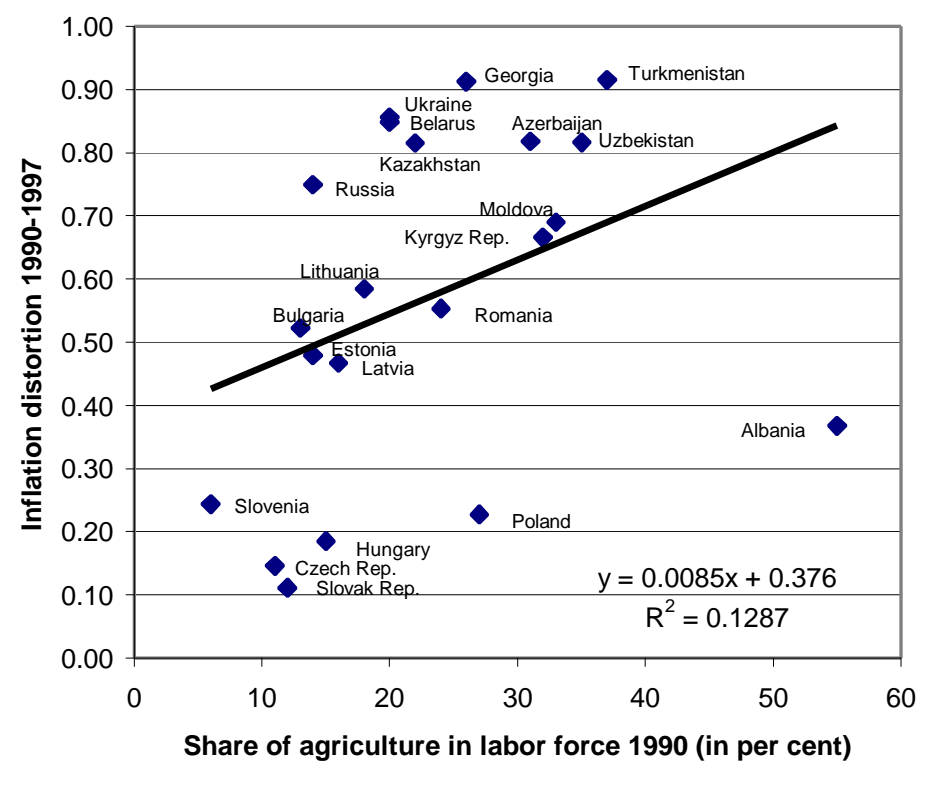

Figure 8. Transition Economies: Economic Growth and Inflation, 1990-1997

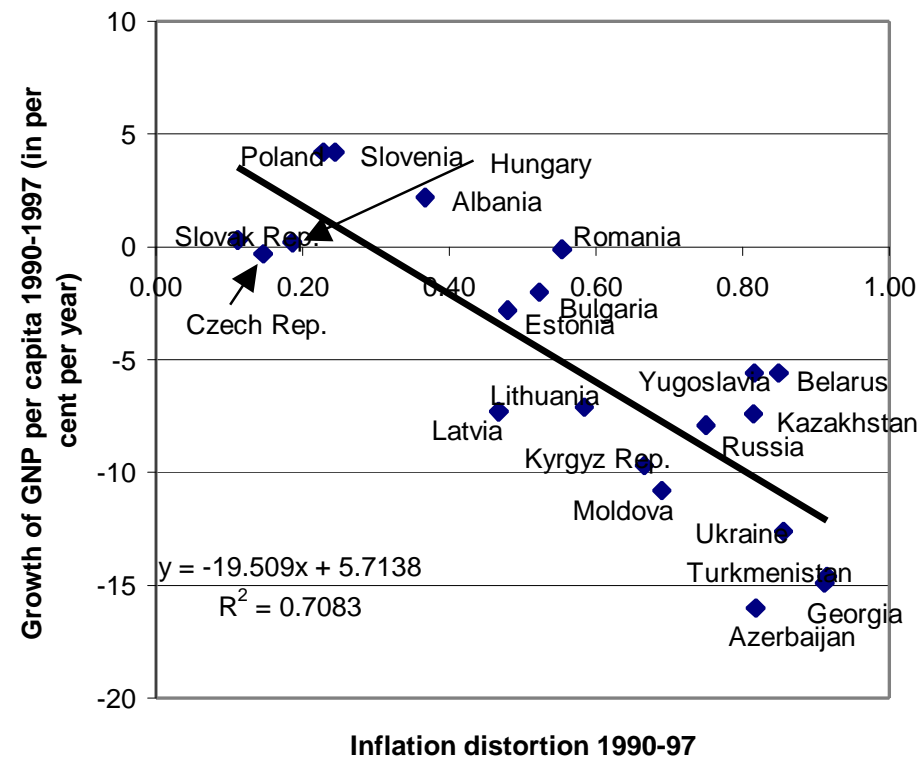



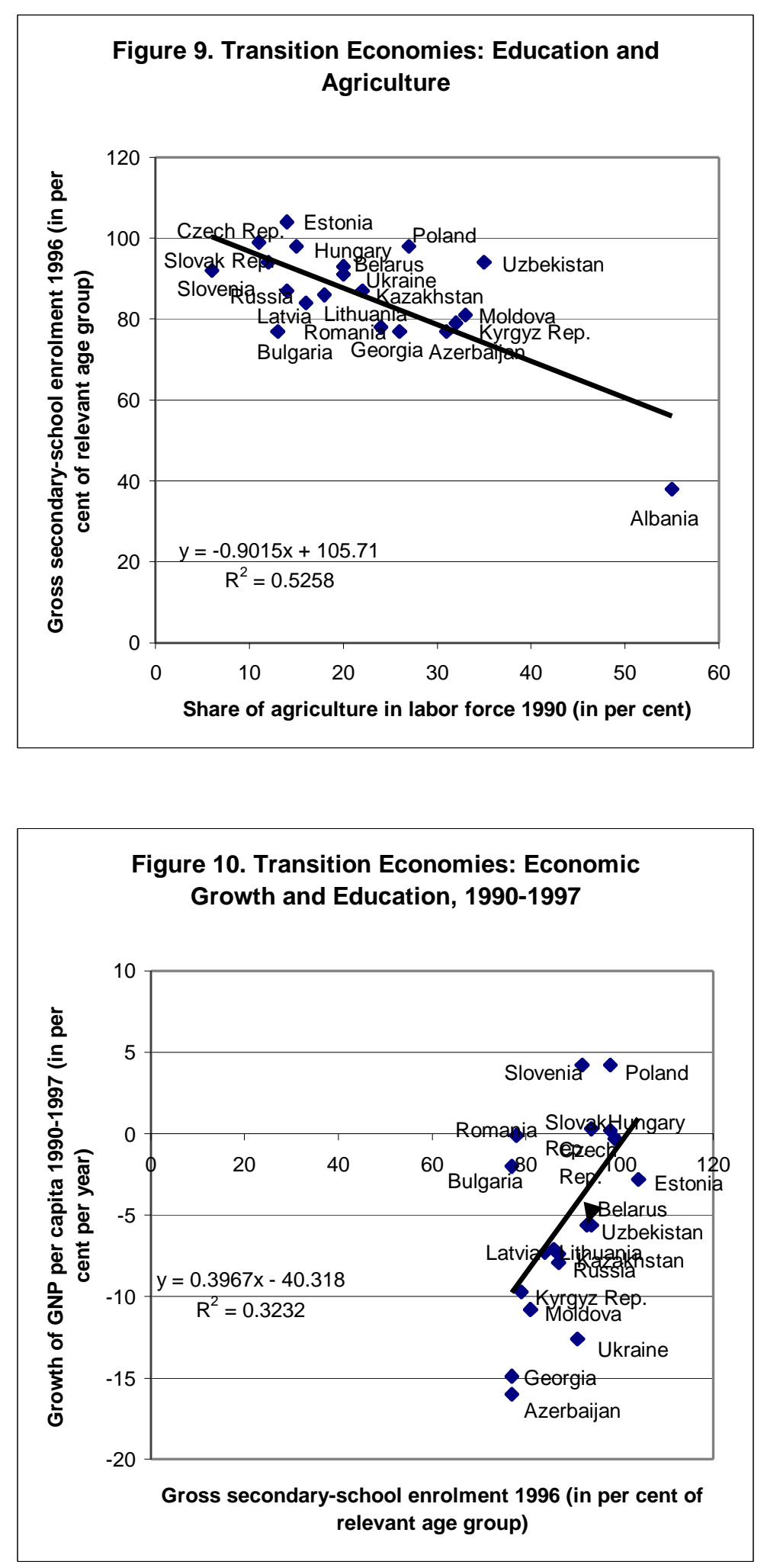

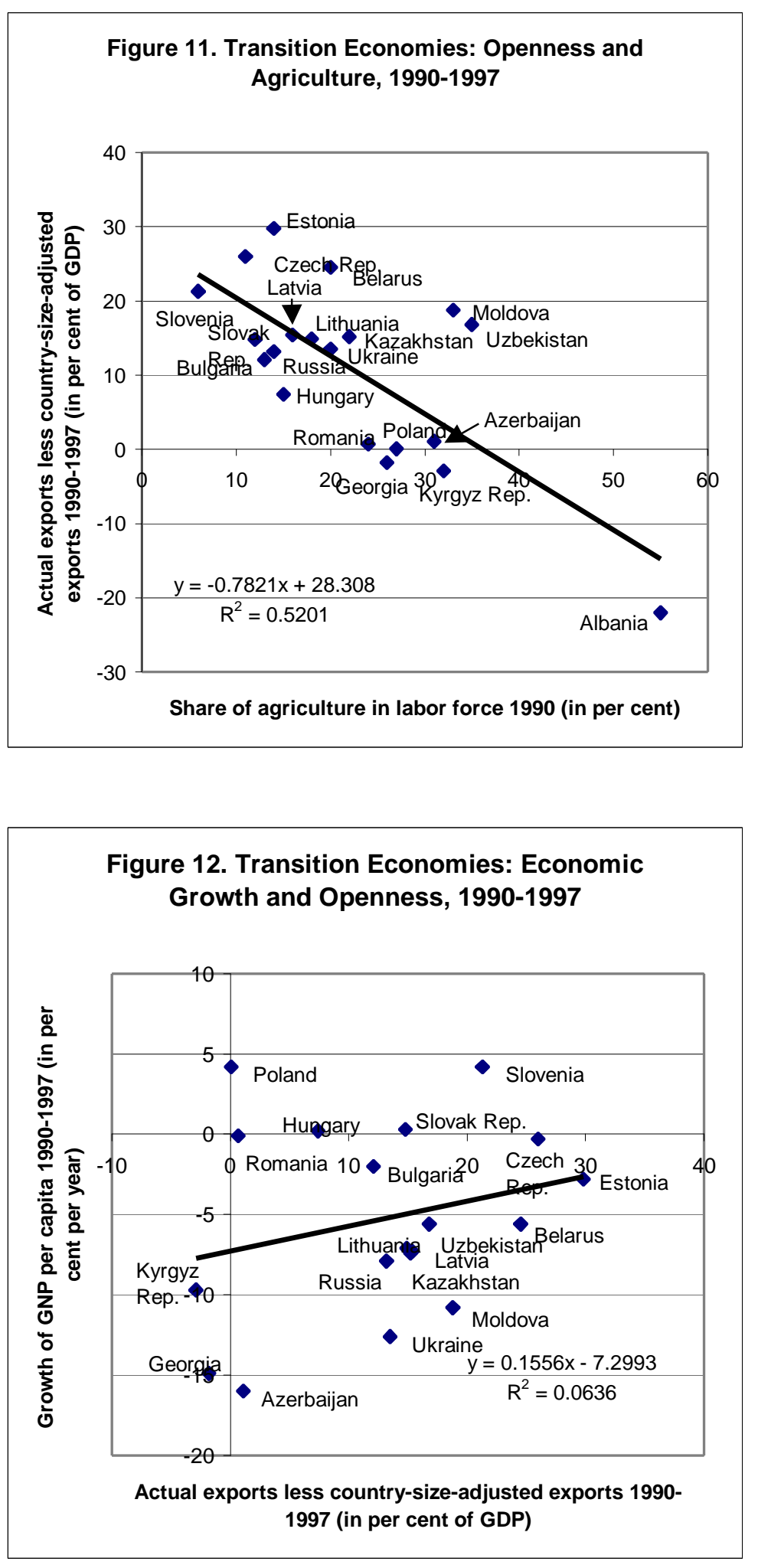


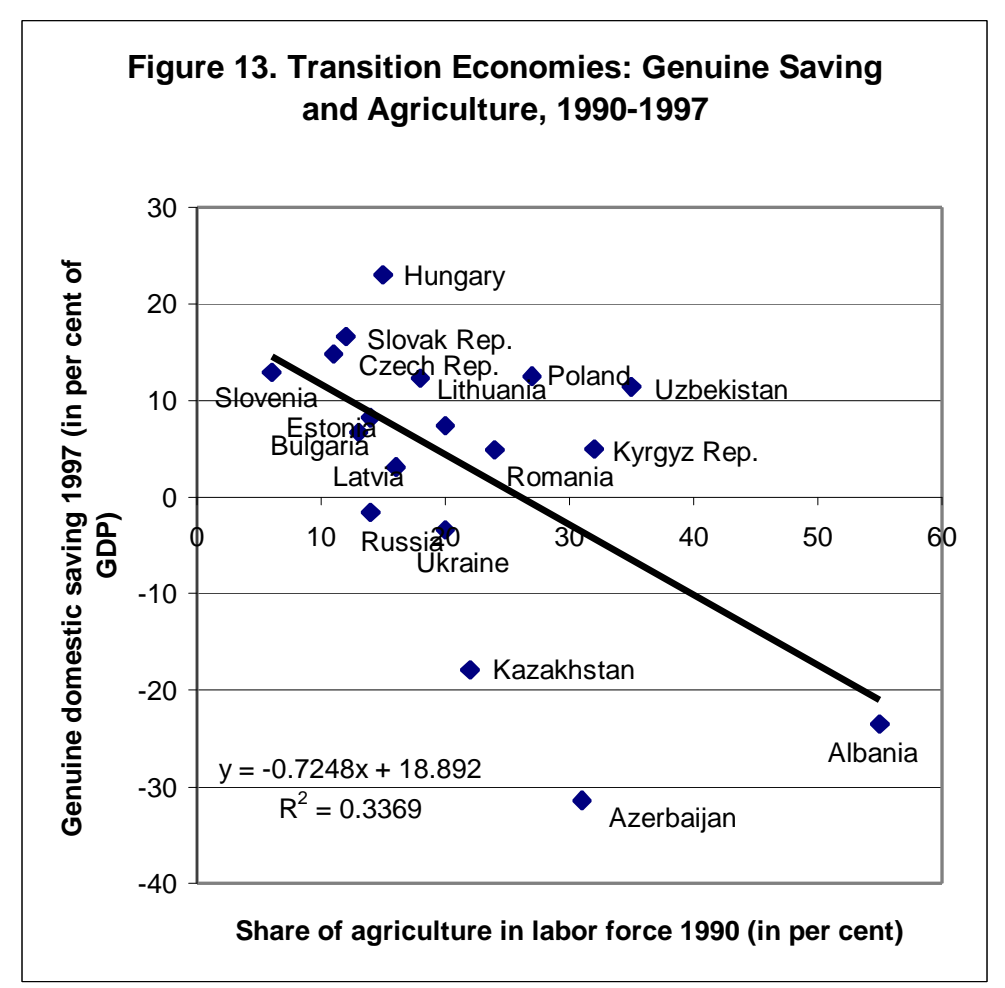

Figure 14. Transition Economies: Genuine Saving and Corruption

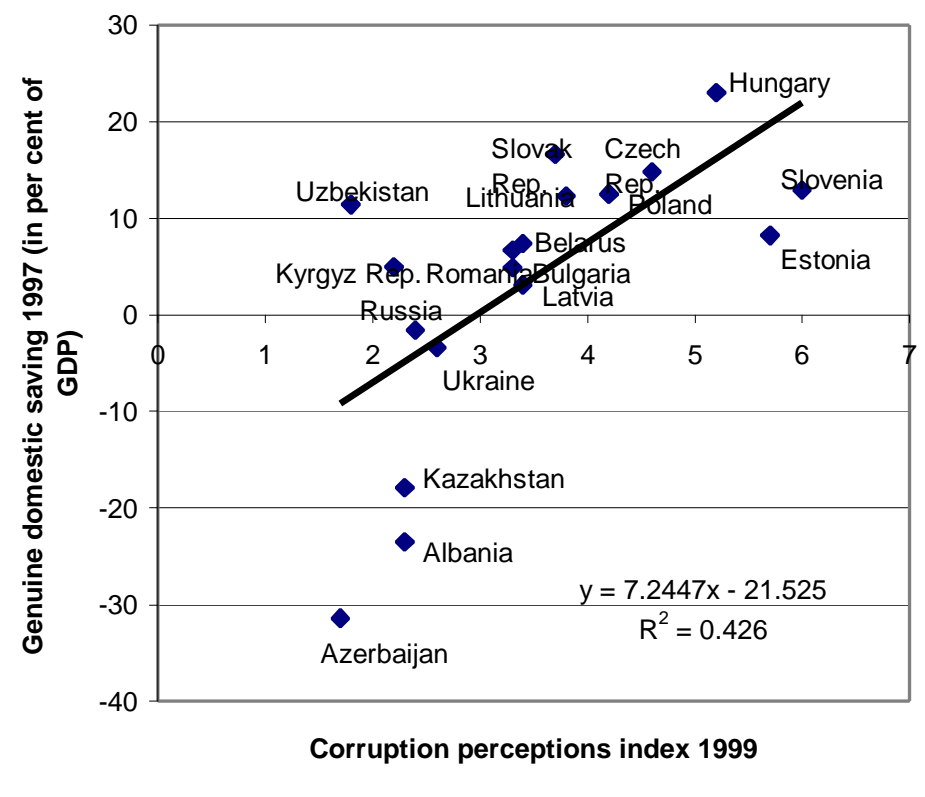



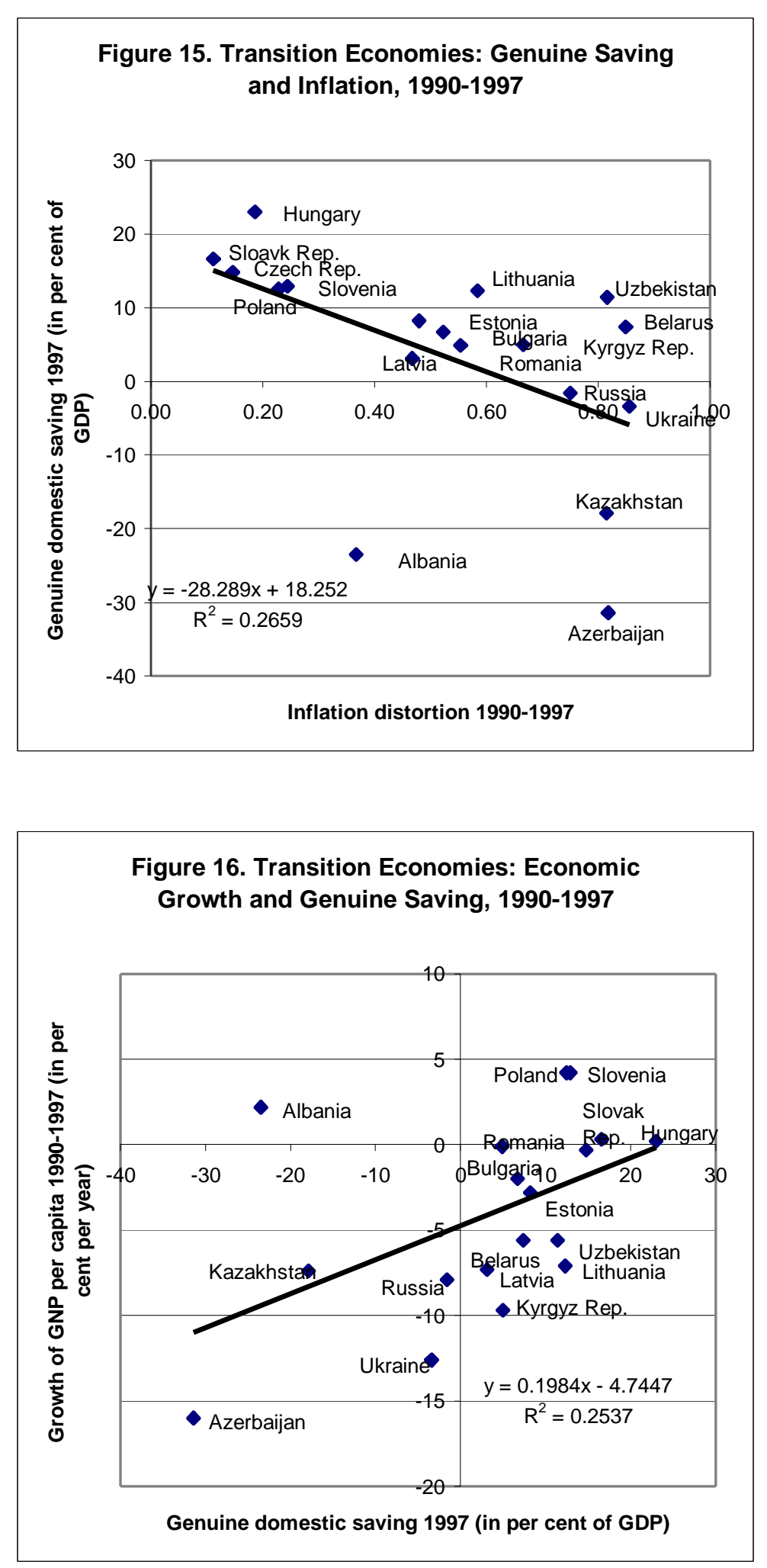


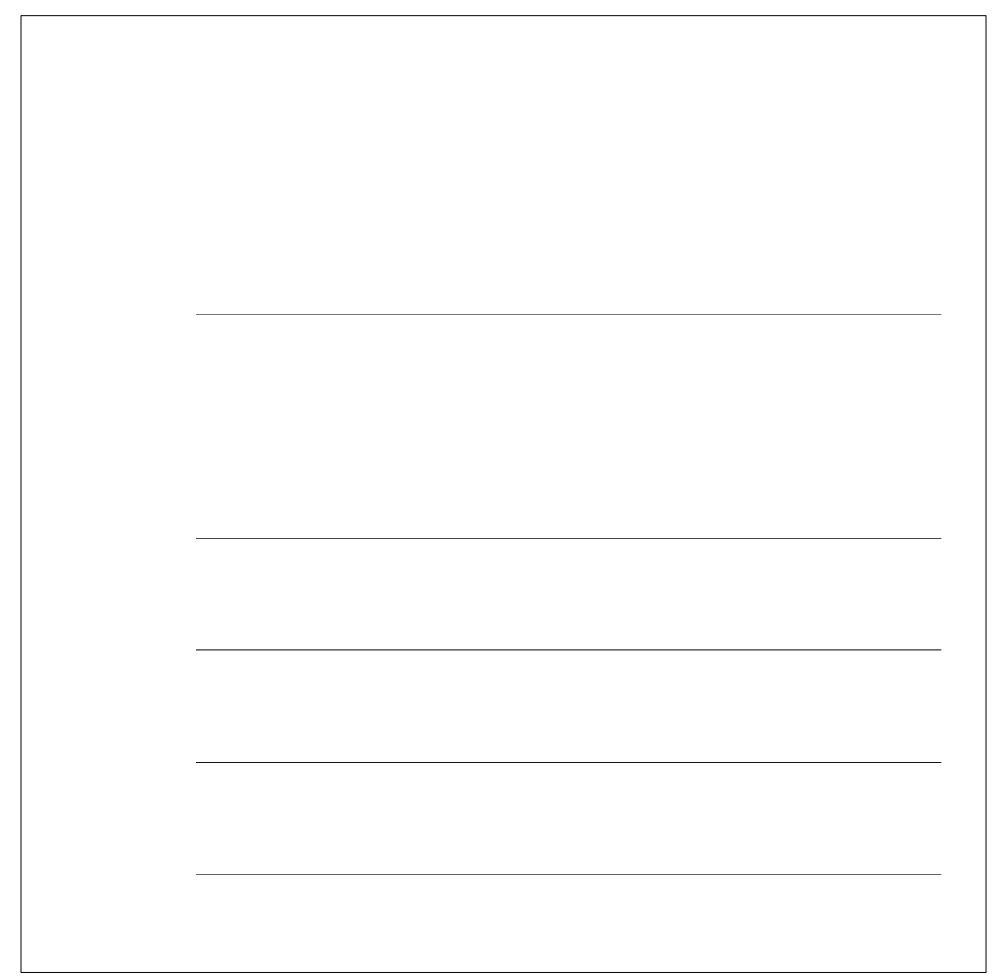

